\title{
A Comparative Analysis of Multi Carrier SPWM Control Strategies using Fifteen Level Cascaded H - bridge Multilevel Inverter
}

\author{
D.Mohan \\ M.E, Lecturer in Dept of EEE, \\ Anna university of Technology, Coimbatore, \\ AMS Engineering College, Namakkal.
}

\author{
Sreejith B.Kurub \\ M.E, Field Engineer, \\ Working in KEC International LTD, \\ UNNAO, Uttar Pradash.
}

\begin{abstract}
In this paper proposes a SPWM control strategy fifteen level cascaded $\mathrm{H}$ - bridge multi level inverter. This method introduce sine wave is compared with the triangular carrier wave with different phase relationship. The carrier based Phase disposition PDPWM, PODPWM, APODPWM have been analyzed in this paper. The PWM control strategy method for multi level inverter to reduce the total harmonics distortion in the output waveform. The simulation is done by matlab / simulink environment.
\end{abstract}

\section{Keywords}

PWM, SPWM, PDPWM, PODPWM, APODPWM

\section{INTRODUCTION}

In recent years multi level inverters are used high power and high voltage applications. Multilevel inverter output voltage produce a staircase output waveform, this waveform look like a sinusoidal waveform. The multilevel inverter output voltage having less number of harmonics compare to the conventional bipolar inverter output voltage. If the multilevel inverter output increase to $\mathrm{N}$ level, the harmonics reduced to the output voltage value to zero. The multi level inverters are mainly classified as Diode clamped, Flying capacitor inverter and cascaded multi level inverter. The cascaded multilevel control method is very easy when compare to other multilevel inverter because it doesn't require any clamping diode and flying capacitor [5].

There are two PWM methods mainly used in multilevel inverter control strategy. One is fundamental switching frequency and another one is high switching frequency. For high switching frequency classified as space vector PWM, Selective Harmonics Elimination PWM and SPWM. Among these PWM methods SPWM is the most used for the multilevel inverter, because it has very simple and easy to implemented. In this paper present SPWM method with the different carrier based disposition PDPWM, PODPWM and APODPWM has been analyzed [3].

\section{CASCADED MULTILEVEL INVERTER TOPOLOGY}

A cascaded multilevel inverter made up of from series connected single full bridge inverter, each with their own isolated dc bus. This multilevel inverter can generate almost sinusoidal waveform voltage from several separate dc sources, which may be obtained from solar cells, fuel cells ,batteries, ultra capacitors, etc. this type of converter does not need any transformer or clamping diodes or flying capacitors [11].

Each level can generate three different voltage outputs $+\mathrm{Vdc}, 0$ and $-\mathrm{Vdc}$ by connecting the dc sources to the ac output side by different combinations of the four switches. The output voltage of an M-level inverter is the sum of all the individual inverter outputs. Each of the Hbridge's active devices switches only at the fundamental frequency, and each H-bridge unit generates a quasisquare waveform by phase-shifting its positive and negative phase legs switching timings. Further, each switching device always conducts for $180^{\circ}$ (or half cycle) regardless of the pulse width of the quasi-square wave so that this switching method results in equalizing the current stress in each active device [7].

This topology of inverter is suitable for high voltage and high power inversion because of its ability of synthesize waveforms with better harmonic spectrum and low switching frequency. Figure 1 shows the power circuit of an eleven level cascaded inverter composed of five full bridge inverters connected in series on each phase [5].

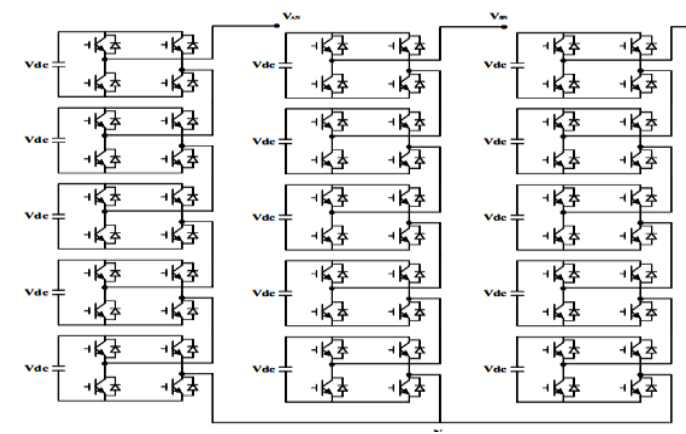

Fig.1: Power circuit of a cascaded eleven level inverter

Considering the simplicity of the circuit and advantages, Cascaded H-bridge topology is chosen for the presented 
work. A multilevel inverter has four main advantages over the conventional bipolar inverter. First, the voltage stress on each switch is decreased due to series connection of the switches. Therefore, the rated voltage and consequently the total power of the inverter could be safely increased. Second, the rate of change of voltage $(\mathrm{dV} / \mathrm{dt})$ is decreased due to the lower voltage swing of each switching cycle. Third, harmonic distortion is reduced due to more output levels. Fourth, lower acoustic noise and electromagnetic interference (EMI) is obtained.

\section{MODELLING $O F$ CASCADED H- BRIDGE INVERTER}

For each full bridge inverter the output voltage is given by

$$
V_{0 i}=V_{d c}\left(S_{1 i}-S_{2 i}\right)
$$

And the input dc current is

$$
I_{d c i}=I_{a}\left(S_{1 i}-S_{2 i}\right)
$$

Where,

(a) $\quad \mathrm{i}=1 \ldots 7$ (number of full bridge inverters employed) for the 15 level type.

(b) $I_{\mathrm{a}}$ is the output current of the cascaded inverter.

(c) $\quad S_{1 i}$ and $S_{2 i}$ are the upper switch of each full bridge inverter.

Now the output voltage of each phase of the multilevel cascaded inverter is given by:

$$
V_{0 n}=\sum V_{0 i} \quad \mathrm{i}=1,2 \ldots \mathrm{n}
$$

\section{CARRIER BASED DISPOSITION PWM METHOD}

This work is done utilizing the simplicity of multi carrier sine PWM. This is explained in the following paragraph. For an $n$-level inverter, $n-1$ carriers with the same frequency $f c$ and the same amplitude $A c$ are disposed such that the bands they occupy are contiguous. The reference waveform has maximum amplitude $A m$, a frequency $f m$, and its zero centered in the middle of the carrier set. The reference is continuously compared with each of the carrier signals. If the reference is greater than a carrier signal, then the IGBT corresponding to that carrier is switched on and if the reference is less than a carrier signal, then the IGBT corresponding to that carrier is switched off [3].

Carrier based disposition PWM methods were first proposed by Carrara et al[2]. Previous works on PWM techniques shows that disposition technique for diode clamped and PSCPWM for cascaded inverter five rises to same harmonic profile for the same number of total switch transition. Hence these techniques can be efficiently applied for Diode Clamped and Cascaded Multilevel Inverter. The phases of carrier signals are rearranged to produce three main disposition techniques known as PD, POD and APOD [2].

Carrier Disposition method arrange N-1 carrier waveform of same amplitude and frequency in continuous bands to fully occupy the linear modulation range of the inverter. The reference or modulating wave is positioned at the center of the carrier set, and continuously compared with the carriers to obtain the necessary gating pulses [3].

In multilevel inverters, the amplitude modulation index $\left(\mathrm{m}_{\mathrm{a}}\right)$ is the ratio of reference amplitude $\left(\mathrm{A}_{\mathrm{m})}\right.$ to carrier amplitude $\left(\mathrm{A}_{\mathrm{c}}\right)$.

$$
m_{a}=A_{m} /(m-1) A_{c}
$$

The frequency ratio $\left(\mathrm{m}_{\mathrm{f}}\right)$ is ratio of carrier frequency $\left(\mathrm{f}_{\mathrm{c}}\right)$ to reference frequency $\left(f_{m}\right)$.

$m_{f}=f_{c} / f_{m}$

\subsection{Phase Disposition Modulation Method (PDPWM)}

In phase disposition method all the carriers have the same frequency and amplitude. Moreover all the N-1 carriers are in phase with each other. It is based on a comparison of a sinusoidal reference waveform with vertically shifted carrier waveform as shown in figure 2 . This method uses $\mathrm{N}-1$ carrier signals to generate $\mathrm{N}$ level inverter output voltage [3]. All the carrier signals have the same amplitude, same frequency and are in phase [7]. In this method fourteen triangular carrier wave have compared with the one sinusoidal reference wave.

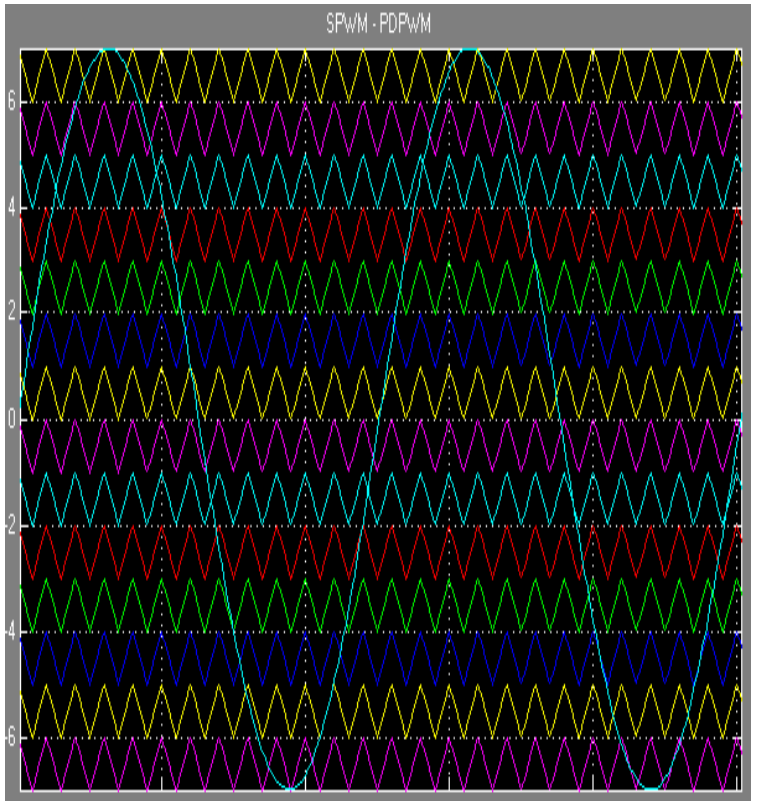

Fig. 2: Phase Disposition Modulation 


\subsection{Phase Opposition Disposition PWM (PODPWM)}

In Phase Opposition Disposition (POD), the carrier signal above the zero axis all the carrier wave have same frequency, same amplitude and in phase each other. But the below the zero axis all the carrier wave have same frequency, same amplitude and in phase but all carrier wave have phase shifted 180 degree compare to the above zero axis carrier waveform [3].

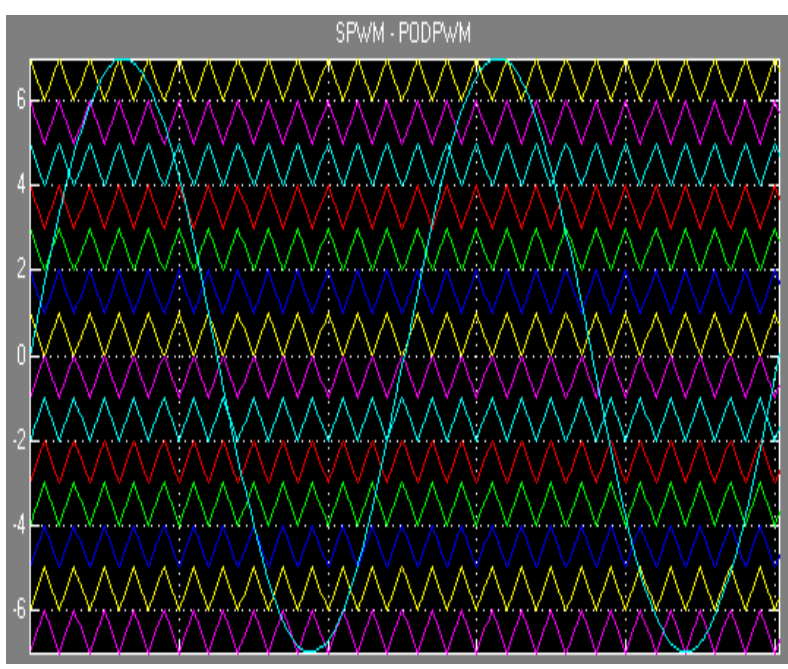

Fig. 3: Phase Opposition Disposition

\subsection{Alternate Phase Opposition Disposition PWM (APODPWM)}

In Alternate Phase Opposition Disposition PWM (APOD), every carrier waveform is out phase with its neighboring carrier wave by 180 degree as shown in figure 4. All the carrier waveform have same frequency, same amplitude and but compare one carrier waveform to neighbor carrier waveform is phase shifted 180 degree. Odd carrier waveforms are in phase but compare to even carrier waveform are out of phase shift 180 degree in odd carrier waveform [3].

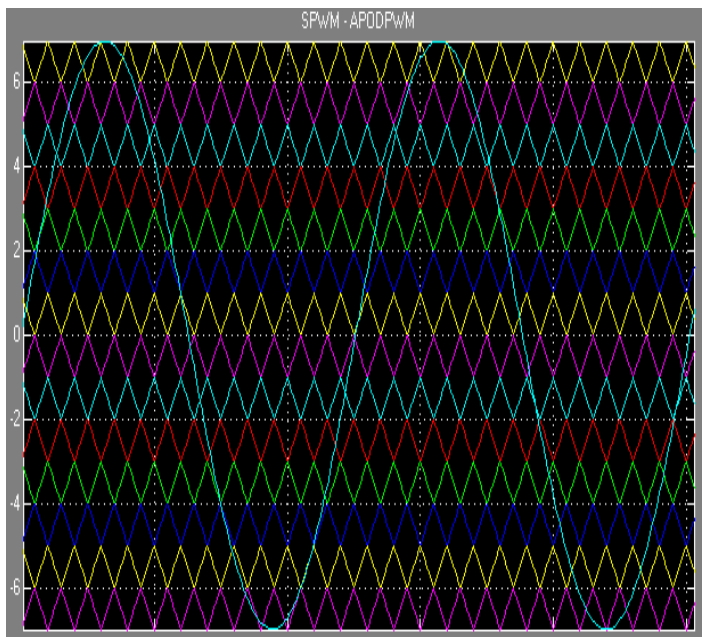

Fig. 4: Alternate Phase Opposition Disposition

\section{SIMULATION}

The fifteen level cascaded $\mathrm{H}$ bridge multi level inverter is simulated in matlab / simulink environment. The various method of the carrier based disposition analysis and gets the output waveform in the fifteen level inverter. SPWM generation circuit contains fourteen carrier wave and one reference sine wave, then compared signal is given to the corresponds IGBTS to the multilevel inverter.
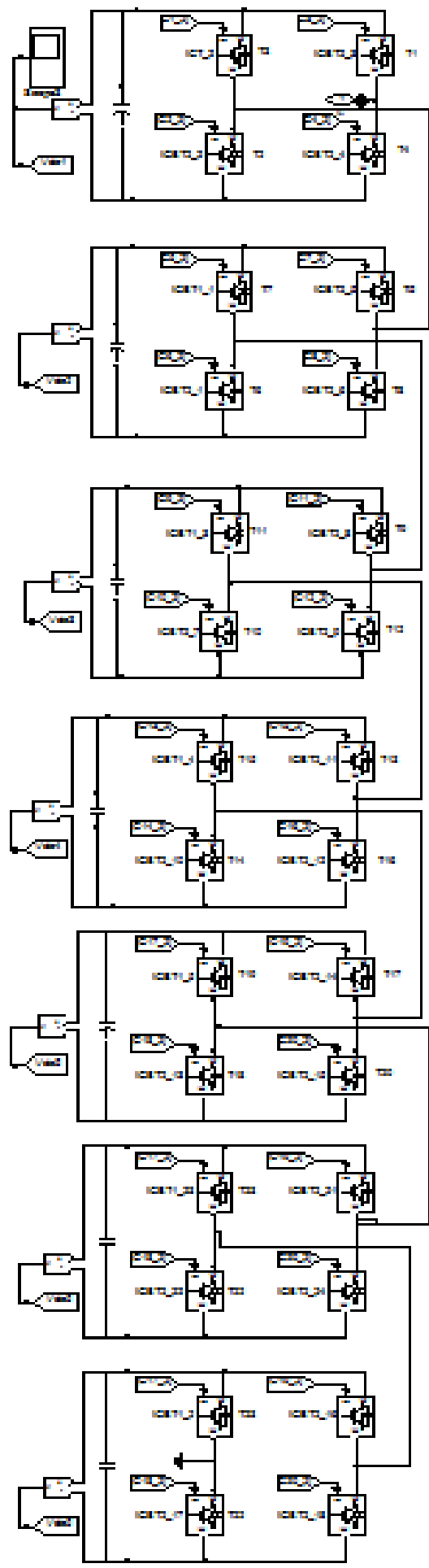

Fig. 5: Simulation Diagram of Fifteen Level Inverter 


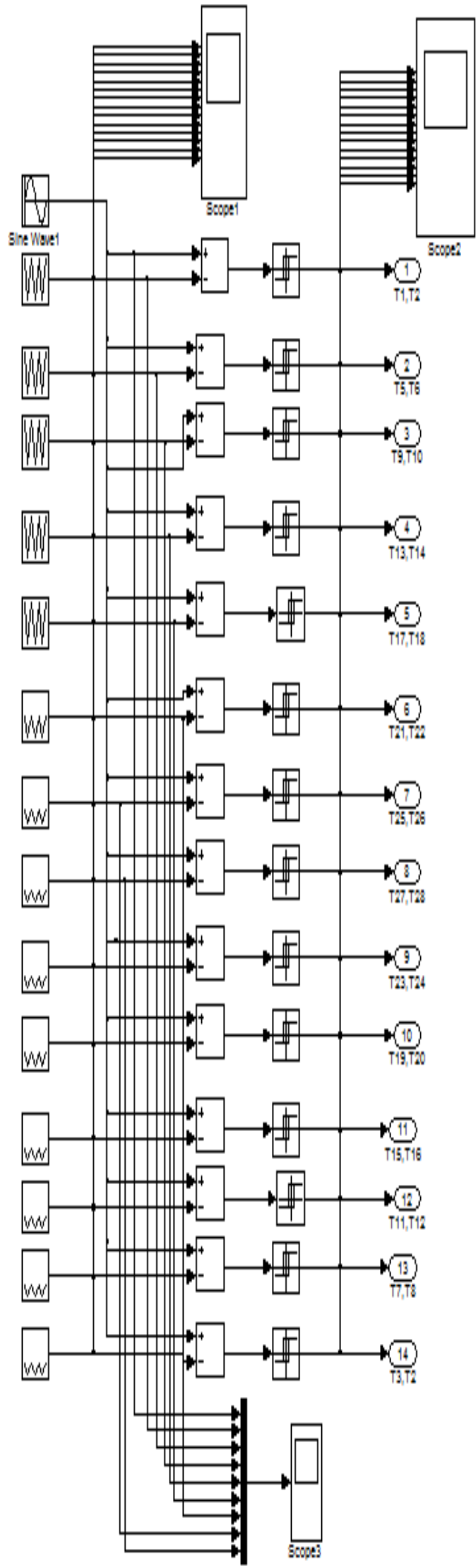

Fig .6: SPWM generator circuit for fifteen level inverter

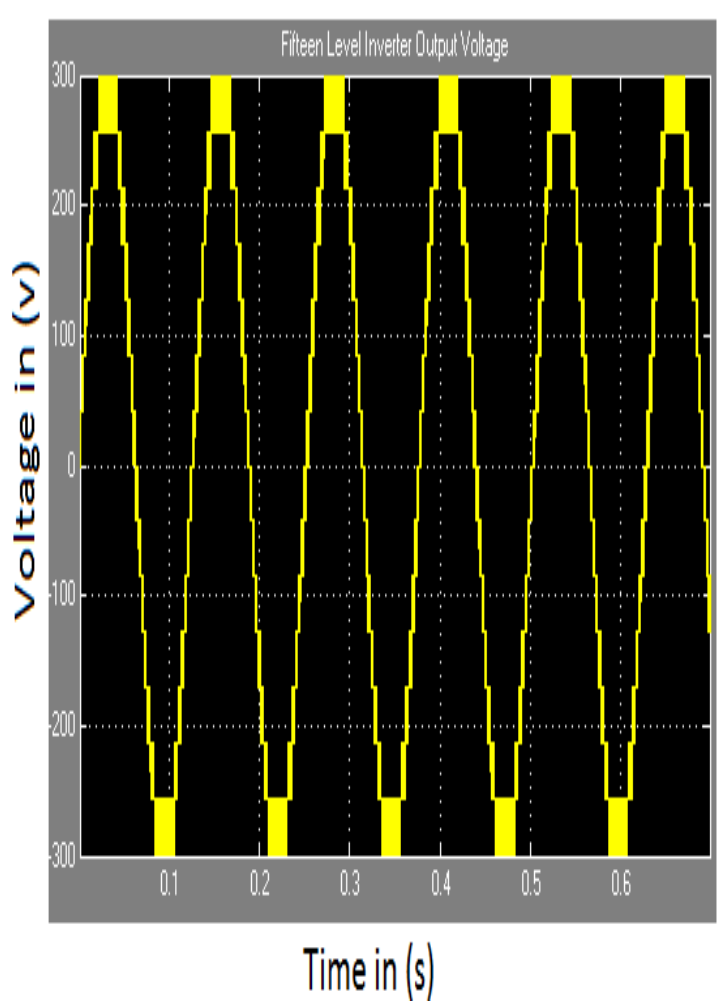

Fig. 7: Fifteen level inverter output voltage

Table 1

\% THD for different PWM

\begin{tabular}{|l|l|l|l|}
\hline MI & PD & POD & APOD \\
\hline 0.5 & 20.12 & 22.13 & 24.86 \\
\hline 0.6 & 17.54 & 19.13 & 22.78 \\
\hline 0.7 & 15.12 & 17.39 & 18.37 \\
\hline 0.8 & 13.89 & 16.94 & 17.14 \\
\hline 0.9 & 8.41 & 10.76 & 12.14 \\
\hline
\end{tabular}

\section{CONCLUSION}

The SPWM control strategy method for the fifteen level cascaded $\mathrm{H}$ bridge multi level inverter has been presented in this paper. The carrier based disposition of PDPWM, PODPWM, APODPWM method have simulated and results have been tabulated. The PDPWM method has given the better results for all modulation indexes. The simulation of fifteen level cascaded $\mathrm{H}$ bridge multi level has been designed and simulated as MATLAB / Simulink environment. The different kinds of modulation index and load have simulated in the simulation but better results are tabulated in this paper. 


\section{REFERENCES}

[1] B.P.Mcgrath and D.G Holmes "reduced n PWM harmonic distortion for multi level inverters operating over a wide modulation range" IEEE Transactions on power electronics vol 21 no 4 pp941-949, july 2006

[2] G. Carrara, S. Gardella, M. Marchesoni,R. Salutari, G. Sciutto, "A New MultilevelPWM Method: A Theoretical Analysis," IEEETransactions on Power Electronics, vol. 7, no. 3,July 1992, pp. 497-505.

[3] Leon M.Tolbert and Thomas G. Habetler "Novel multilevel inverter carrier based PWM method" IEEE Transaction On Industry Application Vol 35 No 5 Sep 1999 pp 1098-1107

[4] Aglidis and M.Calasis "Application specific harmonic performance evaluation of multi carrier PWM techniques" in IEEE PESC, pp 172-178

[5] J.Rodríguez, J.S.Lai, and F. Z.Peng,"Multilevel Inverters: A Survey ofT opologies, Controls, and Applications", IEEETransactions on Industrial Electronics, Vol. 49,No. 4, August 2002,pp.724-739

[6] H.Y Wu, X.N He "Research on PWM control of cascade Multilevel converter" Proc of the Third International conference on Power Electronics and Motion Control, pp 1099- 1103, 2000.

[7] B.P.Mcgrath and D.G Holmes "Multi carrier PWM strategies for multilevel inverter" IEEE Transaction on Industrial Electronics, Volume 49, Issue 4, Aug 2002, pp 858-867

[8] Martha Calais, Lawrence J.Borlel Vassilios G. Agelidis "Analysis of Multi carrier PWM Methods for a single phase five level inverter" IEEE

\section{AUTHOR PROFILE}

D.Mohan received B.E degree in Electrical and Electronics Engineering and M.E Degree in Power Electronics and Drives from Alagappa Chettiar College of Engineering and technology, Karaikudi in 2007 and 2010 respectively. He is currently working as a Lecturer in Electrical and Electronics Engineering Department of Annai Mathammal Sheela Engineering College, Namakkal, India. His field of interests includes power quality, power electronics and control system.
Transaction on Power electronics , July 2001,pp 1351-1356

[9] D.GHolmes, and B.P.McGrath,"Opportunities for Harmonics cancellation with Carrier based PWM for Two level and multilevel cascaded inverters," in conf.Rec.IEEE/IAS Annual Meeting,1999.

[10] Tianhao Tang, Jingan Han, Xinyuan Tan, "Selective Harmonic elimination for a cascaded multilevel inverter " IEEE Transation on Industrial Electronics,2006 IEEE international Symposium, volume2, July 2006, pp997-981

[11] D.Mohan and Sreejith B.Kurub "Performance Analysis of Multi Level Shunt Active Filter based on SDM" in CiiT International Journal of Digital Signal Processing pp42 - 46

[12] Villanueva, E. Correa, P. Rodriguez, J. Pacas, M "Control of a Single-Phase Cascaded H-Bridge Multilevel Inverter for Grid-Connected Photovoltaic Systems" IEEE Transation on Industrial Electronics, volume56, Nov 2009 pp 4399 - 4406

[13] G. Carrara, D. Casini, S. Gardella, and R. Salutari, "Optimal PWM for the control of Multilevel voltage source inverter," Fifth European Conf. on Power Electronics and application. pp. 255- 259, Vol. 4, Brighton, UK, 13-16 Sep. 1993.

[14] Nabae A., Takahashi I., Agaki H., A New NeutralPoint-Clamped PWM, Inverter, IEEE Transactions on Industry Applications, Vol. IA-17, No. 5, Sep.Oct., 1981.

[15] D.G. Holmes, T.A.Lipo," Modern Pulse Width Modulation Techniques for Power Converter", IEEE Press, 2003

Sreejith B Kurup received BE degree in Electrical and Electronics Engineering from Alagappa Chettiar College of engineering and Technology, Karaikudi and M.E Degree in Power Electronics and Drives from Government college of Technology, Coimbatore in 2007 and 2009 respectively. He currently is working in KEC International LTD, UNNAO, Uttar Pradesh, India. His fields of interests include power electronic converters, power quality, and electrical drives. 